\title{
CASHEW NUT MEAL IN THE FEEDING OF BROWN LAYING HENS
}

\author{
Farelo da castanha de caju na alimentação de poedeiras marrons
}

\author{
Carlos Eduardo Braga Cruz ${ }^{1}$, Ednardo Rodrigues Freitas², Regina Patrícia de Souza Xavier², \\ Danilo Rodrigues Fernandes ${ }^{2}$, Germano Augusto Gerônimo Nascimento ${ }^{2}$, Pedro Henrique Watanabe ${ }^{2}$
}

\begin{abstract}
The use of alternative foods to replace conventional foods is becoming a source of research for many researchers. The cashew nut meal (CNM) has high energy and protein value, may be a partial substitute for corn and soybean meal for poultry feed. In this context, this research was conducted to evaluate the effect of inclusion of CNM on the utilization of nutrients in the ration for laying hens, as well as the performance and characteristics of the eggs. The study used 180 Dekalb Brown laying hens 27 weeks of age, distributed in a completely randomized design with six treatments and five replicates of six birds. Treatments consisted of a control diet without CNM and others with the inclusion of this food at levels of 5, 10, 15, 20 and 25\%. Upon regression analysis, a linear increase in nitrogen metabolism, crude energy and apparently metabolizable energy was seen. The dry matter digestibility and metabolizable energy corrected for rations were not affected by the inclusion of the CNM. Feed intake and egg weight were not affected by the inclusion of the CNM; however, egg production, egg mass, feed conversion, and yolk color worsened linearly with inclusion of CNM. Compared to control diet, the inclusion of CNM worsened the egg mass and feed conversion from $15 \%$, and yolk color from $20 \%$. As a result, it is recommended the inclusion of the CNM in the diet of laying hens at a maximum level of $10 \%$.
\end{abstract}

Index terms: Alternative food, digestibility, egg characteristics.

\section{RESUMO}

O uso de alimentos alternativos, em substituição aos alimentos convencionais, vem se tornando fonte de pesquisa para muitos pesquisadores. O Farelo da Castanha de Caju (FCC) apresenta alto valor energético e proteico, podendo ser substituto parcial do milho e do farelo de soja para a alimentação de aves. Neste contexto, o experimento foi conduzido para avaliar o efeito da inclusão do FCC sobre a utilização dos nutrientes da ração por poedeiras comerciais, bem como o desempenho e características dos ovos. Foram utilizadas 108 poedeiras Dekalb Brown com 27 semanas de idade, distribuídas em delineamento inteiramente casualizado com seis tratamentos e três repetições de seis aves. Os tratamentos consistiram de uma ração testemunha sem FCC e os demais, da inclusão desse alimento nos níveis de 5, 10, 15, 20 e 25\%. Conforme análise de regressão, houve aumento linear na metabolização do nitrogênio, energia bruta e da energia metabolizável aparente. A digestibilidade da matéria seca e os valores de energia metabolizável corrigida das rações não foram influenciados pela inclusão do FCC. O consumo de ração e o peso dos ovos não foram afetados pela inclusão do FCC, entretanto, a produção de ovos, massa de ovo, conversão alimentar e a coloração da gema pioraram linearmente com a inclusão. Em relação ao controle, a inclusão de FCC piorou a massa do ovo e a conversão alimentar, a partir de $15 \%$, e a coloração da gema, a partir de $20 \%$. Conforme os resultados, o FCC pode ser incluído na ração de poedeiras até o nível de $10 \%$.

Termo para indexação: Alimento alternativo, digestibilidade, características dos ovos.

\section{INTRODUCTION}

In recent years, research results regarding the evaluation of unconventional foods for feeding birds have been common in international and national literature. Two justifications are often given for the interest in the development of studies in this area. The first is the expectation of reducing the cost of feeding, with the possibility of replacing conventional foods used in the composition of the diets, for example, corn and soybean meal. The second is the possibility of using an agroindustrial residue for a more noble purpose, which will add value to the production chain.
Among the alternative foods that can be found in Northeastern Brazil, cashew nut meal (CNM), a byproduct resulting from processing of almonds for human consumption, can be highlighted. According to Rodrigues et al. (2003), about 2 to $5 \%$ of the products of almond cashew nuts are inappropriate for human consumption, and classified as scrap; however, this can be processed into meal used for animal feed. This product presents a composition (Embrapa, 1991; Silva et al. 2008) that confers high energy and protein and, on the basis of these characteristics, can be a partial substitute for corn and soybean meal in poultry nutrition.

${ }^{1}$ Universidade Federal do Ceará/UFC - Departamento de Zootecnia - Avenida Mister Hull - 2977 - Campus do Pici - Bloco 807 - Fortaleza - CE Brasil - carlos.zootecnia@gmail.com

2Universidade Federal do Ceará/UFC - Departamento de Zootecnia - Fortaleza - CE - Brasil

Received in july 28, 2014 and approved in october 15, 2014

Ciênc. Agrotec., Lavras, v.39, n.1, p.68-74, jan./fev., 2015 
According to Onifade et al. (1998) and Oyebimpe et al. (2006), CNM can be compared with whole soybean, which is characterized as a moderate source of protein and an excellent source of energy, because it contains high fat. Considering these characteristics, research has been performed to evaluate the inclusion of CNM in poultry feed. Sogunle et al. (2006) and Freitas et al. (2006) investigated the viability of the inclusion of CNM in the diet of broiler chickens at levels of $15 \%$ and $25 \%$, respectively. In addition, Ojewola, Okoye and Agbakuru (2004) and Agebede (2006) verified, respectively, the viability of replacing the protein from soybean meal by CNM in the feed of broilers, at levels of $75 \%$ in the period from 22 to 63 days of age and $50 \%$ in the period 35 to 56 days of age. In those researches, the levels recommended for CNM inclusion in the diets were 30 and $28.3 \%$, respectively.

In a study with laying hens, Onifade et al. (1999) found that the use of up to $31.5 \%$ of CNM allowed the inclusion of fibrous foods in the diet without causing damage to the poultry performance. Odunsi (2002) reported the viability of including up to $20 \%$ of CNM in the diet of laying hens with regard to growth and egg laying. Sogunle et al. (2009) found that the level of 30\% CNM in combination with $10 \%$ cassava zests resulted in better results for growing pullets. On the other hand, Soares et al. (2007) recommended the inclusion of up to $16 \%$ of CNM in diet of laying quails.

Given the above, the objective of this research was to evaluate the effects of including CNM in the ration on nutrient utilization, performance and egg characteristics of brown commercial layers.

\section{MATERIAL AND METHODS}

This study used 180 Dekalb Brown laying hens aged 27 weeks of age, distributed in a completely randomized design with six treatments and five replicates of six birds.

The birds were housed in galvanized wire cages $(50 \times 50 \times 45 \mathrm{~cm})$, with a nipple drinking system, trough type feeder and collector of eggs, each containing two birds.

At the beginning of the experiment, the birds were weighed individually (1770 $\mathrm{kg} \pm 100 \mathrm{~g})$ and distributed so that all treatments were composed of repetitions with birds of similar weights.

Treatments consisted of a control diet without CNM and others with the inclusion of this food at levels of 5,10 , 15,20 and $25 \%$. The experimental diets were formulated with corn, soybean meal, oil and CNM, including an inert substance (washed sand) to maintain the same level of nutrients in all diets (Table 1).

For the calculation of rations, the values of chemical composition and metabolizable energy proposed in table of Embrapa (1991) were considered for CNM and for the other ingredients from Rostagno et al. (2011). Also, were considered the nutritional requirements proposed by management manual of strain.

During the experimental period, the birds received ration and water ad libitum. To avoid waste, the feeders were supplied twice daily ( 8 p.m. and 4 a.m.). The lighting program used was 16 hours of light per day (artificial + natural).

The collection of eggs was performed daily, and eggs from each parcel were identified and stored for weighing on the following day once per week. After weighing, three eggs per repetition were selected for determining the quality of the eggs.

The feed intake ( $\mathrm{g} /$ bird/day), feed conversion ( $\mathrm{g} / \mathrm{g}$ ), percentage of laying (\%/bird/day), egg weight (g), egg mass (g/bird/day), percentage of egg yolk, albumen and shell (\%), and egg yolk color (Roche colorimetric scale) were evaluated.

The metabolism trial, using the total collection of excreta, was performed after 63 days of feeding the birds with the experimental diets and lasted four days in total.

To collect the excreta, covered trays with plastic under cages were installed; to identify the excreta from the diets fed during the test, $1 \%$ of iron dioxide was added to the diet on the first and last days of collection, so that on the first day the marked excreta were collected and the last day the excreta without iron dioxide were collected. The excreta were collected twice daily ( $8 \mathrm{p}$. $\mathrm{m}$. and 4 a. m.), packed in plastic bags, identified by repetition and frozen.

At the end of the experimental period the amount of feed consumed and the total amount of excreta produced were determined. After thawing at ambient temperature, the excreta of each repetition were homogenized to remove a sample, which was sent to the laboratory of animal nutrition along with the samples of experimental diets, and were dried in a forced ventilation oven at $55^{\circ} \mathrm{C}$ for 72 hours. Then, samples of excreta were ground in a knife mill and a sample was removed for the determination of dry matter and nitrogen, according to the methodology described by Silva and Queiroz (2002). Also, the crude energy was determined using an adiabatic bomb calorimeter (Model 1242, Parr Instruments Co. EUA.). 
CRUZ, C. E. B. et al.

Table 1 - Percentage and calculated composition of diets to laying hens containing different levels of cashew nut meal (CNM).

\begin{tabular}{|c|c|c|c|c|c|c|}
\hline \multirow{2}{*}{ Ingredients } & \multicolumn{6}{|c|}{ Levels of CNM (\%) } \\
\hline & 0 & 5 & 10 & 15 & 20 & 25 \\
\hline Corn & 58.13 & 56.48 & 53.82 & 48.16 & 42.51 & 36.86 \\
\hline Soybean meal & 28.25 & 26.30 & 24.45 & 23.22 & 21.88 & 20.59 \\
\hline CNM & 0.00 & 5.00 & 10.00 & 15.00 & 20.00 & 25.00 \\
\hline Soy Oil & 2.40 & 1.05 & 0.00 & 0.00 & 0.00 & 0.00 \\
\hline Calcitic lime & 8.71 & 8.64 & 8.58 & 8.51 & 8.44 & 8.37 \\
\hline Dicalcium phosphate & 1.75 & 1.76 & 1.78 & 1.80 & 1.82 & 1.84 \\
\hline Vitamin supplement ${ }^{1}$ & 0.20 & 0.20 & 0.20 & 0.20 & 0.20 & 0.20 \\
\hline Mineral supplement ${ }^{2}$ & 0.05 & 0.05 & 0.05 & 0.05 & 0.05 & 0.05 \\
\hline DL - methionine $99 \%$ & 0.15 & 0.14 & 0.15 & 0.17 & 0.18 & 0.19 \\
\hline L- Lysine & 0.00 & 0.02 & 0.04 & 0.04 & 0.05 & 0.05 \\
\hline Common salt & 0.36 & 0.36 & 0.35 & 0.35 & 0.35 & 0.35 \\
\hline Inert $^{3}$ & 0.00 & 0.00 & 0.58 & 2.50 & 4.52 & 6.50 \\
\hline \multirow[t]{2}{*}{ Total } & 100.00 & 100.00 & 100.00 & 100.00 & 100.00 & 100.00 \\
\hline & \multicolumn{6}{|c|}{ Calculated Composition } \\
\hline Metabolizable Energy (kcal/kg) & 2850 & 2850 & 2850 & 2850 & 2850 & 2850 \\
\hline Crude Protein (\%) & 18.00 & 18.00 & 18.00 & 18.00 & 18.00 & 18.00 \\
\hline Calcium (\%) & 3.80 & 3.80 & 3.80 & 3.80 & 3.80 & 3.80 \\
\hline Available Phosphorus(\%) & 0.43 & 0.43 & 0.43 & 0.43 & 0.43 & 0.43 \\
\hline Sodium $(\%)$ & 0.18 & 0.18 & 0.18 & 0.18 & 0.18 & 0.18 \\
\hline Total Lysine (\%) & 0.93 & 0.93 & 0.93 & 0.93 & 0.93 & 0.93 \\
\hline Total Methionine (\%) & 0.43 & 0.43 & 0.43 & 0.43 & 0.43 & 0.43 \\
\hline Methionine + Total cysteine $(\%)$ & 0.72 & 0.72 & 0.72 & 0.72 & 0.72 & 0.72 \\
\hline Threonine $(\%)$ & 0.65 & 0.65 & 0.65 & 0.65 & 0.65 & 0.65 \\
\hline Tryptophan (\%) & 0.20 & 0.20 & 0.20 & 0.20 & 0.20 & 0.20 \\
\hline
\end{tabular}

${ }^{1}$ Vitamin supplement (supplied per kg of product): 7950 UI vit. A; $1.95 \mathrm{mg}$ vit. $\mathrm{B}_{1} ; 13.05 \mathrm{mcg}$ vit. $\mathrm{B}_{12} ; 4.95 \mathrm{mg}$ vit. $\mathrm{B}_{2} ; 3.30 \mathrm{mg}$ vit. $\mathrm{B}_{6}$; $2200 \mathrm{UI}$ vit. $\mathrm{D}_{3} ; 10.95 \mathrm{mg}$ vit. E; $1.80 \mathrm{mg}$ vit. $\mathrm{K}_{3} ; 0.81 \mathrm{mg}$ folic acid; $12.0 \mathrm{mg}$ calcium pantothenate; $0.51 \mathrm{~g}$ choline; $36.0 \mathrm{mg}$ niacin; ${ }^{2}$ Mineral supplement (supplied per kg of product): $10 \mathrm{mg}$ Copper; $50 \mathrm{mg}$ zinc; $40 \mathrm{mg}$ iron; $65 \mathrm{mg}$ manganese; $1 \mathrm{mg}$ iodine; antioxidant $10.2 \mathrm{~g}$; coccidiostat $1.02 \mathrm{~g}$; selenium $0.15 \mathrm{mg}$;

${ }^{3}$ Washed sand.

Based on the laboratory results, dry matter digestibility coefficients (DMDC), nitrogen (NDC), crude energy (CEDC) and the apparent metabolizable energy (AME) and apparent corrected (AMEn) were calculated.

Statistical analyses of the data were performed using the SAS (2002). The degrees of freedom relating to the inclusion levels of the CNM, excluding the control diet (zero level of inclusion of the CNM), were deployed in polynomials to establish the curve that best described the behavior of the data. To compare the results obtained with each inclusion level related to those obtained with the level of zero CNM (control), the Dunnett test (5\%) was used.

\section{RESULTS AND DISCUSSION}

The results obtained in the metabolism trial are shown in table 2. According to the regression analysis, there was a linear increase in NDC (Figure 
1), CEDC (Figure 1) and AME value of feed (Figure 1 ), increasing the metabolism of nitrogen and crude energy, respectively, by $0.90 \%$ and $0.20 \%$, and the value of AME by $9.27 \%$, for each $1 \%$ increase of CNM in diets. However, the metabolism of dry matter and the value of apparent metabolizable energy corrected for rations were not affected by the inclusion of CNM in the ration.

The average comparison by Dunnett test $(5 \%)$ showed that there was no significant difference between the results obtained with the inclusion of the CNM at different levels and those obtained with the control $(0 \% \mathrm{CNM})$ for all variables.

Table 2 - Dry matter digestibility coefficients (DMDC), nitrogen (NDC), crude energy (CEDC) and the apparent metabolizable energy (AME) and apparent corrected metabolizable energy (AMEn) of rations.

\begin{tabular}{|c|c|c|c|c|c|c|c|c|}
\hline \multirow{2}{*}{ Evaluated Parameters } & \multicolumn{6}{|c|}{ Inclusion levels of CNM } & \multirow{2}{*}{ Average } & \multirow{2}{*}{$\begin{array}{c}\text { SEM }^{2} \\
(\%) \\
\end{array}$} \\
\hline & 0 & 5 & 10 & 15 & 20 & 25 & & \\
\hline DMDC (\%) & 70.05 & 67.02 & 70.40 & 67.38 & 70.12 & 68.14 & 68.85 & 5.12 \\
\hline $\operatorname{NDC}(\%)^{1}$ & 25.21 & 20.29 & 26.80 & 29.85 & 32.90 & 34.68 & 29.96 & 29.35 \\
\hline $\operatorname{CEDC}(\%)^{1}$ & 78.66 & 75.89 & 78.08 & 78.02 & 79.82 & 80.19 & 78.44 & 2.94 \\
\hline $\operatorname{AME}(\mathrm{Kcal} / \mathrm{Kg} \mathrm{MS})^{1}$ & 3221 & 3117 & 3149 & 3195 & 3198 & 3375 & 3193 & 2.87 \\
\hline AMEn (Kcal/Kg MS) & 3152 & 3062 & 3076 & 3114 & 3180 & 3283 & 3111 & 2.34 \\
\hline
\end{tabular}

${ }^{1}$ Linear effect $(\mathrm{P}<0.05) ;{ }^{2} \mathrm{SEM}=$ Standard error of mean.
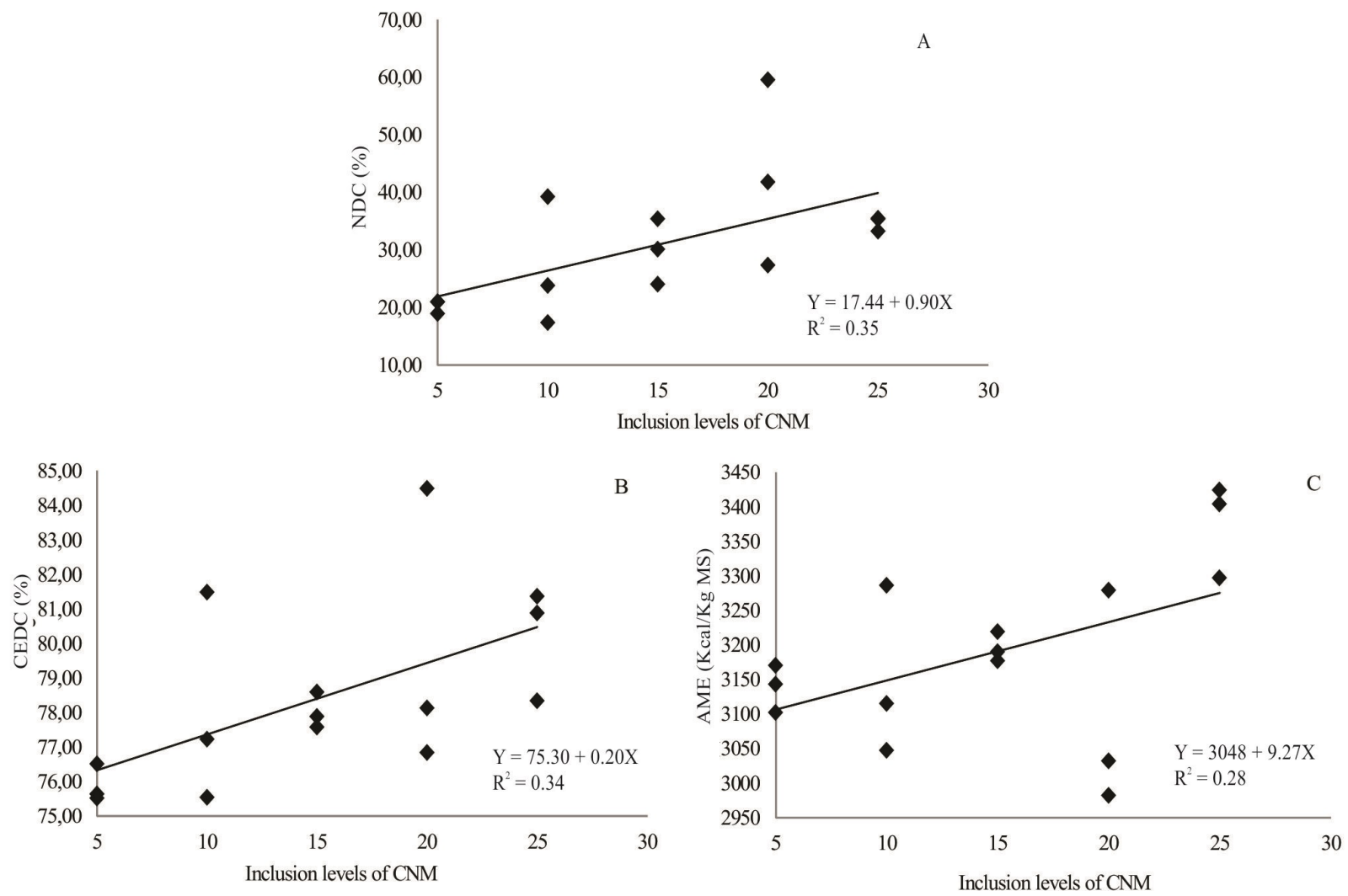

Figure 1 - Nitrogen digestibility coefficients (NDC) (A), crude energy CEDC (B), apparent metabolizable energy AME (C) of laying hens fed diets containing different levels of cashew nut meal (CNM). 
As the CNM is an ingredient that is rich in fat, it is possible that increasing the proportion of fat in diets with the inclusion of CNM has increased the value of the apparent metabolizable energy and the metabolism of nitrogen and crude energy. According to Sakomura et al. (2004), with increasing fat content in the diet of the birds, benefits related to the extra-caloric and extra-metabolic effects of fats may occur, consisting, respectively, of an increase in the availability of nutrients of other ingredients of the ration and an improvement of energy efficiency, resulting in the increased net energy of the ration.

The results obtained in this investigation differ from those reported by Soares et al. (2007), who studied the effects of the inclusion of CNM in the laying diet of Japanese quails. According to those researchers, there was a linear reduction in the metabolism of nitrogen and dry matter of rations with the inclusion of CNM, while the crude energy metabolism and metabolizable energy values did not vary significantly. Compared to controls, only the metabolism of dry matter and nitrogen differed significantly, yielding lower values of these parameters at the level of $20 \%$ of CNM in rations.

The performance results obtained with different levels of CNM in rations are presented in table 3. The inclusion of $\mathrm{CNM}$ in the diet of laying hens did not influence feed intake and egg weight $(\mathrm{P}>0.05)$. However, according to regression analysis, the inclusion of this food at levels above $5 \%$ promoted a linear reduction $(\mathrm{P}<0.05)$ in egg laying (Figure 2) and egg mass (Figure 2), and feed conversion worsened in a linear fashion (Figure 2).

Comparing the results obtained with the different inclusion levels of CNM compared to the control (Dunnett,
$5 \%$ ), it was observed that birds fed the diet containing $20 \%$ CNM produced fewer number of eggs; however, reduced egg mass and feed conversion worsened for the birds fed the diet including $15 \% \mathrm{CNM}$.

Among the factors that may affect egg production is the intake of energy and protein for birds (Pinto et al., 2002; Freitas et al., 2005). On the other hand, protein intake or the intake of the amino acids lysine and methionine can influence egg weights and the ratio of albumen and yolk (Buxadé, 1993). Apparently, these factors would not influence the results described above, since the diets were formulated to be isonutritive and the corrected metabolizable energy and feed intake did not vary significantly among treatments.

On the other hand, Soares et al. (2007) reported that the quality of CNM is quite variable and the level of tannin, which is usually around $0.26 \%$, may increase depending on the processing it has undergone. Furthermore, the protein quality may be compromised by the higher proportion of almonds or almond pieces burned by the heat. Therefore, it is possible that these factors contributed to the reduction of production and egg mass and the decreased feed conversion.

The results partly resemble those reported by Soares et al. (2007), who evaluated the inclusion of the CNM in the laying diet of Japanese quails. According to researchers, including CNM did not affect feed intake and resulted in a linear decrease in egg production, egg weight and egg mass, while feed conversion also worsened. However, only with the inclusion at levels of more than $16 \%$ CNM was the performance significantly different compared to the control group.

Table 3 - Performance and egg characteristics of laying hens fed diets containing different levels of cashew nut meal (CNM).

\begin{tabular}{|c|c|c|c|c|c|c|c|c|}
\hline \multirow[t]{2}{*}{ Evaluated Parameters } & \multicolumn{6}{|c|}{ Inclusion levels of CNM } & \multirow[t]{2}{*}{ Average } & \multirow{2}{*}{$\begin{array}{c}\text { SEM } \\
(\%)\end{array}$} \\
\hline & 0 & 5 & 10 & 15 & 20 & 25 & & \\
\hline Feed intake (g/bird/day) & 100.72 & 100.46 & 102.09 & 99.92 & 101.30 & 97.20 & 100.28 & 3.67 \\
\hline Egg laying $(\% / \text { bird/day })^{1}$ & 87.00 & 84.03 & 84.82 & 81.06 & $79.84 *$ & $74.14 *$ & 81.82 & 4.64 \\
\hline Egg weight (g) & 63.10 & 61.61 & 62.31 & 61.81 & 60.98 & 63.40 & 62.20 & 2.38 \\
\hline Egg mass $(\mathrm{g} / \mathrm{bird} / \text { day })^{1}$ & 54.91 & 51.77 & 52.78 & $50.11 *$ & $48.69^{*}$ & $47.00 *$ & 50.88 & 2.38 \\
\hline Feed conversion $(\mathrm{g} / \mathrm{g})^{1}$ & 1.84 & 1.94 & 1.93 & $1.99 *$ & $2.09 *$ & $2.07 *$ & 1.98 & 4.32 \\
\hline Specific gravity & 1.090 & 1.090 & 1.091 & 1.087 & 1.087 & 1.088 & 1.089 & 0.20 \\
\hline Haugh unit & 85.19 & 85.89 & 82.87 & 84.92 & 86.43 & 85.49 & 85.13 & 3.46 \\
\hline Yolk Color $^{1}$ & 6.99 & 7.02 & 6.59 & 6.44 & $6.26^{*}$ & $5.93 *$ & 6.53 & 3.73 \\
\hline
\end{tabular}

${ }^{1}$ Linear effect $(\mathrm{P}<0.05) ;{ }^{2} \mathrm{SEM}=$ Standard error of mean; * Different compared to control by Dunnett test. 

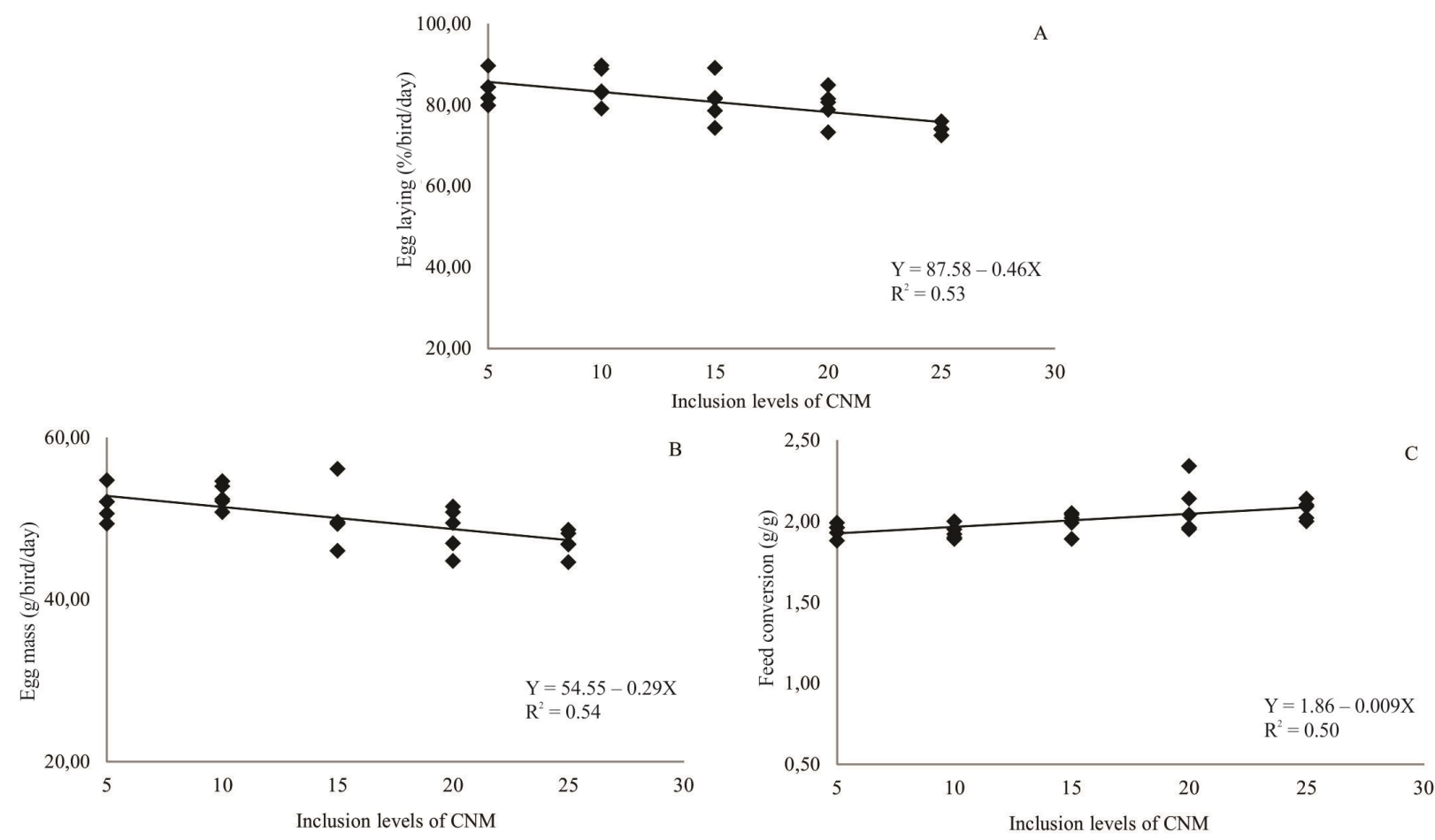

Figure 2 - Egg laying (A), egg mass (B), feed conversion (C) of laying hens fed diets containing different levels of cashew nut meal (CNM).

Contrasting results between the present search and those results of Onifade et al. (1999) and Odunsi (2002), who reported that the increased inclusion of CNM in the diet of laying hens provided a reduction in feed intake without influencing the production, weight, egg mass or feed conversion. According to the researchers, the reduction in feed intake with the increase in the CNM in diet is associated with a wealth of ingredients in fat, making it an excellent source of energy and a moderate source of protein.

With regard to the characteristics of eggs, it was noted that the specific gravity and Haugh unit were not affected by the inclusion levels of CNM, but as the level of CNM increased, the yolks became less pigmented in a linear fashion $\left(\mathrm{Y}=7.09-0.04 \mathrm{X} ; \mathrm{R}^{2}=0.72\right)$. The birds fed the inclusion of the CNM from $20 \%$ produced eggs with yolks that were less pigmented compared to controls (Dunnett, 5\%).

The absence of a significant influence of the inclusion of CNM in the ration on the specific gravity and Haugh unit of eggs was also reported by Onifade et al. (1999) and Odunsi (2002) in studies with laying hens and Soares et al. (2007) with Japanese quail. The reduction in yolk color with the greater inclusion of CNM was also observed by Onifade et al. (1999) and Soares et al. (2007).

According to Soares et al. (2007), the reduced color of yolk when using higher levels of CNM in rations is due to the presence of carotenoids in the diet, which is caused by the reduction in the quantity of corn in diets with the inclusion of CNM. According to Silva, Albino and Godoi (2000) the total or partial replacement of corn by alternative foods that are low in carotenoid pigments in diets for laying hens can reduce egg yolk color, and the intensity depends on the level of substitution.

\section{CONCLUSION}

Cashew nut meal can be used in feed for brown laying hens, but only at a level of up to $10 \%$ in rations.

\section{REFERENCES}

AGBEDE, J.O. Growth indices and muscle development in broiler-chickens fed equi-protein replacement of soyabean meal with discarded cashew nut meal. The Journal of Poultry Science. 43:215-222, 2006. 
BUXADÉ, C.C. El huevo para consumo: bases

productivas. Madrid: Mundi Prensa/Adeos, 1993. 401p.

EMPRESA BRASILEIRA DE PESQUISA E

AGROPECUÁRIA - EMBRAPA. Tabela de

composição química e valores energéticos de alimentos

para suínos e aves. 3.ed. Concórdia: Embrapa, 1991.

p.28-68 (Circular Técnica, 19).

FREITAS, E.R. et al. Farelo de castanha de caju em rações para frangos de corte. Pesquisa Agropecuária

Brasileira. 41(6):1001-1006, 2006.

FREITAS, A.C. et al. Efeito de níveis de proteína bruta e de energia metabolizável na dieta sobre o desempenho de codornas de postura. Revista Brasileira de

Zootecnia. 34(3):838-846, 2005.

ODUNSI, A. A. Effect of feeding reject cashew kernel meal on pre and early-laying performance of pullet.

Archivos de Zootecnia. 51:423-429, 2002.

OJEWOLA, G.S.; OKOYE, F.C.; AGBAKURU, I. Replacement value of cashew-nut meal for soybean meal in finishing broiler chickens. International

Journal of Poultry Science. 3:513-516, 2004.

ONIFADE, A.A. et al. Replacement value of cashew nut meal for groundnut-cake in pullet diets: Effect on pre-laying performance and serum biochemical indices. Indian Journal Animal Science. 68(3):273275, 1998.

.Performance of laying pullets fed on cereal-free diets based on maize offal, cassava peel and reject cashew nut meal. British Poultry Science. 40:84-87, 1999.

OYEBIMPE K, et al. Response of broiler chickens to cassava peel and maize offal in cashewnut meal baseddiets. Archivos de Zootecnia. 55(211):301-304, 2006.

PINTO, R. et al. Níveis de proteína e energia para codornas japonesas em postura. Revista Brasileira de Zootecnia. 31(4):1761-1770, 2002.
RODRIGUES, M.M. et al. Utilização do farelo da castanha de caju na terminação de ovinos em confinamento. Revista Brasileira de Zootecnia. 32(1):240-248, 2003.

ROSTAGNO, H.S. et al. Tabelas brasileiras para aves e suínos: composição de alimentos e exigências nutricionais. Viçosa, MG: Universidade Federal de Viçosa, 2011.

SAS Institute. SAS Users guide: Statistics. Version 8. Carry, NC, 2002.

SAKOMURA, N.K. et al. Efeito do nível de energia metabolizável da dieta no desempenho e metabolismo energético de frangos de corte. Revista Brasileira de Zootecnia. 33:1758-1767, 2004.

SILVA, D.J.; QUEIROZ, A.C. Análise de alimentos: métodos químicos e biológicos. 3.ed. Viçosa, MG: Editora UFV, 2002. 165p.

SILVA, J.H.V.; ALBINO, L.F.T.; GODOI, M.J.S. Efeito do extrato de urucum na pigmentação da gema dos ovos. Revista Brasileira de Zootecnia. 29(5):14351439, 2000.

SILVA, R.B. et al. Composição química e valores de energia metabolizável subprodutos agroindustriais determinados com diferentes aves. Acta Scientiarum. Animal Science. 30(3):269-275, 2008.

SOARES, M.B. et al. Farelo de amêndoa da castanha de caju na alimentação de codornas japonesas na fase de postura. Revista Brasileira de Zootecnia. 36(4):10761082, 2007.

SOGUNLE, O. M. et al. Performance of growing pullets fed cassava peel meal diet supplemented with cashew nut reject meal. Archivos de Zootecnia. 58:23-31, 2009.

.The performance of broiler chicks fed on diets containing rice offal and cashew nut reject meal. Archivos de Zootecnia. 55:273-280, 2006. 